\section{CME: Rheumatology}

December's CME focuses on musculoskeletal (MSK) disorders, which represent a major disease burden and challenges in the developing world, mainly because of lack of resources and poor training in diagnosis and management. Many patients with diseases such as systemic lupus erythematosus and rheumatoid arthritis have reduced life expectancy and face a lifetime of pain and other problems. The advent of the synthetic disease-modifying anti-rheumatic drugs has significantly improved outcomes, but the challenge of early diagnosis and initiation of treatment remains in the developing world - and these drugs are expensive.

MSK disorders still rank highest in prevalence as causes of chronic ill health, long-term disability and consultation with health professionals, as was shown in the Burden of Global Disease 2010 Study. This is against the background of MSK disorders contributing only $3.4 \%$ and $1.7 \%$ of the total disease burden in the developed and developing world, respectively. Osteoarthritis and low back pain remain the largest contributors to the global disability burden. The Bone and Joint Decade 2000 - 2010, endorsed by many organisations including the World Health Organization and many governments, has acknowledged the rising burden of MSK disorders. Dr Ayanda Gcelu and Prof. Asgar Kalla have put together an excellent issue of CME that will provide generalists in all spheres with a greater understanding of these important diseases.

\section{Climate change}

The COP21: Conference of the Parties to the United Nations Framework Convention on Climate Change (UNFCCC), 'Towards an inclusive climate negotiation, ${ }^{[1]}$ is due to take place in Paris in the first week of December, hence our guest editorial, ${ }^{[2]}$ which explores the adverse health effects accruing from the potential $4^{\circ} \mathrm{C}$ rise in temperature in South Africa (SA) and Africa.

Over 190 nations will be represented at the conference, with over 40000 participants and delegates from around the world. Its main focus will be to devise a new international consensus on how the world could keep global warming below $2^{\circ} \mathrm{C}$. For the first time, each country is expected to have announced its contribution towards reducing the impact of climate change, and a report will be made available to the general public before the official commencement of the conference. It is said that a climate fund of USD100 billion per year - the money to be sourced from private and public agencies, from 2020 - from developed countries to assist developing countries in fighting climate change is to be launched. ${ }^{[3]}$

I suspect that we should not hold our respective breaths regarding consensus, or the proposed fund.

We have stressed in earlier issues the adverse health effects of unemployment. Africa's greatest resource is its youth, yet $70 \%$ are without jobs; in SA, over $50 \%$ of young people are jobless. ${ }^{[4]}$ It is said that the climate risk and the job risk, in SA and sub-Saharan Africa, ${ }^{[3]}$ could be addressed simultaneously if the Paris conference prioritises the green economy. According to the South African Green Economy Modelling Report, ${ }^{[5]}$ prioritising investments in the energy sector will maximise the employment creation potential of a green economy. The report further states that 'If the investments are spread equally across all sectors, then the agriculture sector will deliver the highest employment creation potential. ${ }^{[5,6]}$

\section{Genomic research in Africa}

Ramsay ${ }^{[7]}$ outlines the role of the H3Africa Consortium and highlights the need to include Africans in global genomic research, and, importantly, to do so from an African perspective. The H3Africa projects address infectious diseases, including genetic determinants of susceptibility to trypanosomiasis and tuberculosis, and studies on the microbiome in cervical cancer and in respiratory diseases, while six projects focus on the rise of non-communicable diseases (encompassing stroke, diabetes, kidney disease, rheumatic heart disease, obesity and cancer) on the continent.

\section{Ebola update}

As the acute Ebola epidemic in West Africa flickers out (42 days having passed, at the time of writing, without a fresh infection in two of the three countries affected), it was dismaying to learn that the infection has reared its ugly head again: in the case of volunteer Scottish nurse Pauline Cafferkey (reminding us of the virus's tendency to hide in immunologically privileged sites, ${ }^{[8]}$ raising the spectre of unrecognised complications among survivors in countries in which healthcare services were decimated by the outbreak), and a few new cases in Guinea. Statements from the Royal Free Hospital, London, and NHS Greater Glasgow and Clyde said that the 39-year-old nurse, no longer infectious, was well enough to return to Scotland and had been transferred to the Queen Elizabeth University Hospital in Glasgow to complete her hospital treatment. Her condition is stable. ${ }^{[9]}$

During the recent West African Ebola epidemic, SA's own heroes and heroines were among those who 'risked and persisted, sacrificed and saved' and were named Time Person of the Year for 2014. ${ }^{[10]}$ Rosie Burton and Tom Boyles were among them, and offer their own insights in their personal views from the field. ${ }^{[11,12]}$

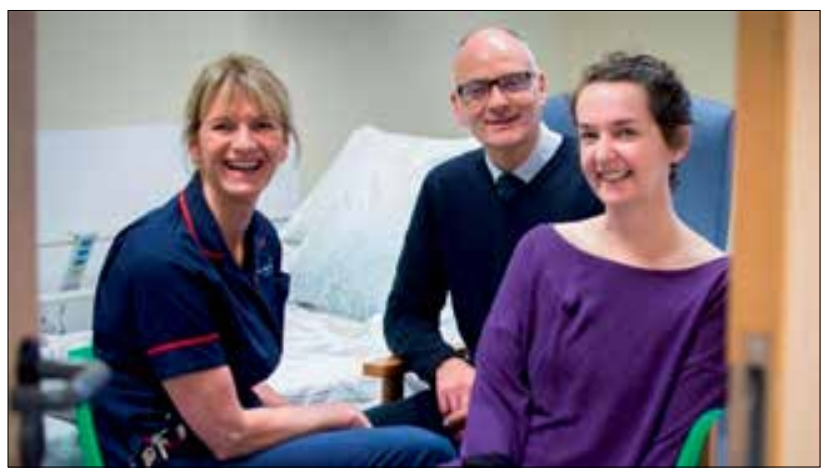

Ms Cafferkey thanked staff at the Royal Free Hospital, including senior matron Breda Athan and consultant Dr Michael Jacob, for the care she had received. ${ }^{[9]}$

\section{To close ...}

The SAMJ wishes its readers, authors and reviewers all best wishes over the holiday season - and easier and happier links in 2016!

JS

1. United Nations Conference on Climate Change. http://www.cop21.gouv.fr/en/cop21-cmp11/cop21main-issues (accessed 16 September 2015)

2. Wright CY, Norval M, Albers PN. Climate change, public health and COP21 - a South African perspective. S Afr Med J 2015;105(12):997-998. [http://dx.doi.org/10.7196/SAMJ.2015.v105i12.10232] COP21: Towards an inclusive climate negotiation in Paris. http://www.csag.uct.ac.za/2015/07/17/cop21-towards-an-inclusive-climate-negotiation-in-paris/ (accessed 16 September 2015).

4. Global Youth Unemployment Trends - a generation at risk. http://www.ilo.org/global/research/globalreports/global-employment-trends/youth/2013/lang-en/index.htm (accessed 16 September 2015).

South African Green Economy Modelling (SAGEM) Report. https://www.environment.gov.za/sites/ default/files/docs/greeneconomy_modellingreport.pdf (accessed 16 September 2015).

6. Modernising agriculture to address youth unemployment in Africa. http://www.sabc.co.za/news/a/5 6. Modernising agriculture to address youth unemployment in Africa. http://www.sabc.co.za/news/a/5
aa916004577a29db0aab7c7c599c9eb/Modernising-agriculture-to-address-youth-unemployment-inAfrica-20141409 (accessed 16 September 2015).

7. Ramsay M. Growing genomic research on the African continent: The H3Africa Consortium. S Afr Ramsay M. Growing genomic research on the African continent: The H3Africa Con
Med J 2015;105(12):1016-1017. [http://dx.doi.org/10.7196/SAMJ.2015.v105i12.10281] Med J 2015;105(12):1016-1017. [http://dx.doi.org/10.7196/SAMJ.2015.v105i12.10281]
Burton R. Ebola: Lessons learned. S Afr Med J 2015;105(9):698-699. [http://dx.doi.org/10.7196/

SAMJnew.8492]

9. BBC news. Ebola nurse Pauline Cafferkey 'has made full recovery'. http://www.bbc.com/news/ukscotland-34791692 (accessed 15 November).

0. Time. Von Drehle D, Baker A. Person of the Year. The Ebola fighters: The ones who answered the call. 10 December 2014. time.com/time-person-of-the-year-ebola-fighters/ (accessed 19 October 2015).

11. Burton R. Ebola: Experiences from the field - Liberia. S Afr Med J 2015;105(12):1006-1008. [http:// dx.doi.org/10.7196/SAMJ.2015.v105i12.10239

12. Boyles TH. Ebola: Personal view from the field - Sierra Leone. S Afr Med J 2015;105(12):1008-1009. [http://dx.doi.org/10.7196/SAMJ.2015.v105i12.9935] 